\title{
URBAN POLICY UNDER NEW LABOUR: A NEW DAWN?
}

\author{
Susan Ball-Petsimeris \\ Département d'Études des Pays Anglophones, University of Paris 8, France \\ e-mail: petsimeris@mrsh.unicaen.fr
}

\begin{abstract}
British urban policies can be collectively characterised as a series of experiments introduced by successive newly elected governments keen to put their own ideological twist on policy for the inner cities and peripheral. The aim of this paper is to examine whether or not, or to what extent, New Labour's urban policy marks a change in policy direction. Following a presentation of the legacy of urban policy left by the outgoing New Right government, the paper will go on to outline New Labour's ideological standpoint. This discussion will provide the context for an examination of the urban policies introduced by the Blair administration.
\end{abstract}

Key words: urban policy, New Deal programme, Great Britain

\section{INTRODUCTION}

There is a widespread consensus among academics and professionals that after three-and-ahalf decades British urban policies can be collectively characterised as a series of experiments introduced by successive newly elected governments keen to put their own ideologycal twist on policy for the inner cities and peripheral estates (see, for example, Atkinson and Moon, 1994; Edwards, 1997; Wilks-Heeg, 1996). In the last decade alone in Britain we have seen the coming and/or going of Enterprise Zones, Urban Development Corporations, Urban Task Forces, City Challenge, Urban Development Grant and City Action Teams, to name but a few. Indeed, in acknowledgement of the large number of programmes which formed the legacy of different governments' urban policies, in 1993 the Single Regeneration Budget was introduced to replace twenty existing programmes from five government departments to provide one consolidated budget for inner city projects.

If British urban policy is characterised by its seemingly short-lived and experimental nature, coupled with its tendency to change alongside each change in government, then perhaps we should have expected very little in the way of anticipation when New Labour won the UK general elections and formed the government in May 1997: yes, urban policy would change, but this was unlikely to be of much consequence. After all, for all the resources and 
efforts invested since 1967 in Britain's inner cities, by 1997 the Department of the Environment's league table of the most deprived small areas had remained largely unchanged. This was not however the case. The leader of New Labour looked forward to 'a new and confident land of opportunity in a new and changing world' (Blair, 1996, p.34), and on the morning of $1^{\text {st }}$ May 1997 there was a considerable degree of anticipation as the end of 18 years of Conservative polices finally came into sight. This anticipation was shared by a number of organisations that had been urging change in urban policy, including the Local Government Association, the Development Trusts Association and the National Council for Voluntary Organisations.

The aim of this paper is to examine whether or not, or to what extent, New Labour's urban policy marks a change in policy direction. Following a presentation of the legacy of urban policy left by the outgoing New Right government, the paper will go on to outline New Labour's ideological standpoint. This discussion will provide the context for an examination of the urban policies introduced by the Blair administration.

\section{THE LEGACY OF THE NEW RIGHT}

There is no doubt that the most influential determinants of the direction of urban policy in the mid-1990s were the New Right governments of Margaret Thatcher and John Major. The New Right's emphasis of urban policy was on property-led regeneration and the promotion of the enterprise culture. The private sector was given the key role in promoting the enterprise culture in regeneration and in challenging the non-entrepreneurial culture associated with public sector initiatives. This effective privatisation of urban policy was most apparent in the 1980s and is therefore closely associated with Thatcherism. Another crucial strand of Thatcherism was the centralisation of government through diluting the power of big Labour-controlled Metropolitan authorities.

In pursuits of its objectives, the Thatcher government used the Urban Development Corporations (UDCs) as the spearhead of inner city policy both presentationally and as consumer of urban funding. The story of the UDCs is well known, and we need not dwell on it here. Designed to exclude local authorities, the UDCs forged a new exclusive alliance between central government and major private property and development interests. In fact, the imperative of urban policy under Thatcher can be broadly characterised as exclusionary: through the process of privatisation and centralisation, the potential contribution to policy of those who did not speak the language of 'enterprise' was minimised.

By the late 1980s the approach represented by the UDCs was attracting increasing levels of criticism (Lawless, 1989; and Parkinson and Evans, 1989). The election of John Major as the leader of the Conservatives in 1990 gave new impetus to the need for a reappraisal of urban policy, and in 1991 City Challenge was introduced. The essence of this programme was competition between local authorities for urban money. Each competitor was required to draw up a detailed action plan for the regeneration of an area and have this approved by Ministers. They must also demonstrate that they have formed a partnership between: the local authority, local business people, residents, voluntary agencies and other 
public agencies. The Department of the Environment then funded successful project bids for five years, after which they were deemed to have finished.

There are two conflicting interpretations about whether the change in prime minister and the introduction of City Challenge meant the continuation or the end of the political aims of Thatcherite urban policy. For Oatley (1995), the City Challenge initiative was primarily a more subtle approach by which central government could continue to diminish the role of local government and to change its character through the introduction of the enterprise culture. He cites the introduction of competition into the allocation of urban funding as the way in which this was achieved. Hambleton and Thomas (1995) argue, however, that many of those involved in the practice of urban regeneration welcomed City Challenge for re-engaging a wider range of interests in the regeneration process, for allowing local authorities a key strategic role, and for including the voice of local community organisations (at least in theory).

In 1993 Major introduced his second urban policy: the Single Regeneration Budget (SRB). As mentioned above, the SRB was to replace twenty existing programmes from five government departments to provide one consolidated budget for urban projects. The money was made available (mainly, but not exclusively) to local authorities on a project bid basis and a showing of proper partnership arrangements. The objectives of the SRB were stated by the Department of the Environment in Building on Success (1993), which re-introduced cooperation and partnership within a generally softer approach to urban policy. Reference was still made to economic growth, competitiveness and the local economy; but emphasis was also placed on a number of concerns that had disappeared from the urban policy agenda, namely: disadvantage, minorities, health, culture and sports. The idea of promoting equality of opportunity, now most often associated with New Labour, was also prominent amongst the objectives of the SRB.

Of equal importance to this new combination of objectives, Major's government made it clear that place-specific urban policies would only be add-ons to mainstream policies, and that the latter would remain the principal means of dealing with the problems of the urban areas. By placing the emphasis on national policies in such fields as housing, unemployment, health, income support and education, Major presented a more modest assessment of the role of urban policy in meeting the social and economic needs of the inner cities and peripheral estates.

The change in the mix of urban policy objectives and the stress placed on the wider field of social policies marked a sea-change between Thatcher and Major. The ostentation of the UDCs was replaced by a more modest and realistic approach to deprivation. Before going on to look at how urban policy has changed since New Labour took office in May 1997, it is first necessary to outline New Labour's ideological standpoint.

\section{NEW LABOUR AND IDEOLOGY}

In the context of opposition to the Conservative governments of Thatcher and Major between 1979 and 1997, and particularly after their 1987 defeat, the Labour Party began to 
articulate an ideology and rhetoric of 'new realism'. In recognition of the fact that Thatcherism had changed the agenda of British politics, new realism proposed that the Labour Party rethink its projects and objectives. The modernising tendency (New Labour) was confirmed in 1994 when Tony Blair became the party leader and set to work on rebuilding Labour. In the same year, the British sociologist Anthony Giddens, often referred to as 'Blair's guru', published what was to be the first in a series of publications proposing a major rethink of social democracy (Giddens 1994, 1998a and 2000). While this broad history is generally agreed, considerable difficulty remains in specifying precisely the politics and approach of Blair and New Labour. Harris (1998) rightly claims that this has less to do with the progress of government, and more to do with the lack of progress of the 'intelligentsia'.

Part of the problem in understanding what New Labour stands for is that it does not fit into any convenient category of Left or Right. This has led much of the discussion of Blair's approach to government to focus on 'the Third Way'; a term which itself suggests a need to have a unified ideology. Giddens makes clear his own use of the term as a shorthand for the modernization of social democracy and its adaptation to a profoundly changed world.

'I shall take it 'third way' refers to a framework of thinking and policy-making that seeks to adapt social democracy to a world which has changed fundamentally over the past two or three decades. It is a third way in the sense that it is an attempt to transcend both old-style social democracy and neoliberalism.' (1998a, p26)

While many people would agree with this broad definition, the boundaries of the Third Way debate remain ill-defined and confusing. This is in part due to the media's generally superficial treatment of the discussions taking place among left-of-centre parties, practitioners and intellectuals, and the occasional indiscriminate use of the term by politicians. However, it is also a function of the fact that the term is relatively new and like other 'isms' prone to elasticity. Endorsed by politicians as diverse as Tony Blair and Bill Clinton, the Third Way is in a period of experimentation during which it remains open to the charge of excessive heterogeneity. Once the intelligentsia has subjected its variants to sufficient examination, the Third Way may also be allowed to take its place alongside liberalism, conservatism, socialism, neo-liberalism, Thatcherism, and the other 'isms' accepted by political theorists. ${ }^{1}$ Until this time, however, the only way to treat the Third Way is to examine the more serious formulations put forward by the leading academics working in this field, most notably, Giddens.

The sub-title of Giddens' principle work dealing with the Third Way is: the renewal of social democracy (Giddens, 1998a). It is therefore fitting that he starts by demonstrating to social democrats the need to understand that the world has changed substantially since the time when the traditional left was forged. The 'welfare consensus' that dominated the industrial countries was exhausted by the late 1970s. The electorate has changed: the left can no longer rely on the industrial working class, instead it has to enter into new kinds of dialogue with an electorate that upholds postmaterialist values. Likewise, social policy has not kept pace with changes in the nature and definition of the family. And the standard prac-

\footnotetext{
${ }^{1}$ On this point see Gidden's own summary of the main critcisms of the Third Way in Giddens (2000) pp. 22-26.
} 
tices used by social democrats to manage the economy are no longer able to cope with the changes brought about by technological innovation and globalization.

Against this background the economic and social policies of the old left are dead. However, the essence of Third Way politics is that social democracy defined as a set of enduring values is very much alive. In the words of Tony Blair:

'The Third Way stands for a modernised social democracy, passionate in its commitment to social justice and the goals of the centre-left, but flexible, innovative and forwardlooking in the means to achieve them. It is founded on the values which have guided progressive politics for more than a century - democracy, liberty, justice, mutual obligation and internationalisation. But it is a third way because it moves decisively beyond the Old Left preoccupied by state control, high taxation and producer interests; and a New Right treating public investment, and often the very notions of 'society' and collective endeavour, as evils to be undone.' (Blair, 1998, p.1, emphasis in the original)

The Third Way is presented as a value-driven program of social democratic renewal, in which policies may evolve against a background of constant values.

Rejecting both the old left and the new right, the Third Way is presented by Giddens as 'a radical centre'. In this way Giddens identifies the Third Way as a relational concept to be found in between, but not equidistant from, the traditional left and the neo-liberal right (Table 1).

Table 1: The Third Way I

\begin{tabular}{|l|l|l|}
\hline $\begin{array}{l}\text { Social Democracy } \\
\text { (The old left) }\end{array}$ & $\begin{array}{l}\text { Neo-Liberalism } \\
\text { (The new right) }\end{array}$ & $\begin{array}{l}\text { The Third Way } \\
\text { (The centre left) }\end{array}$ \\
\hline Class politics of the left & Class politics of the right & Modernising movement of the centre \\
\hline Old mixed economy & Market fundamentalism & New mixed economy \\
\hline $\begin{array}{l}\text { Corporatism: state dominates } \\
\text { over civil society }\end{array}$ & Minimal state & New democratic state \\
\hline Internationalism & Conservative nation & Cosmopolitan nation \\
\hline $\begin{array}{l}\text { Strong welfare state, protecting } \\
\text { from 'cradle to grave' }\end{array}$ & Welfare safety-net & Socialist investment state \\
\hline
\end{tabular}

Source: Giddens (1998b, p.18).

Freedon (1998) also takes a relational approach to defining the Third Way, but this time placing it somewhere between liberalism, conservatism and socialism (Table 2). While these relational approaches are instructive, they do as much in helping to identify what the Third Way is as what it is not. Indeed, as Freedon points out, the Third Way is an eclectic mix of ideological sources. It accepts the needs of global markets but adds key elements of social well-being; principles which find widespread support amongst the British electorate.

One consequence of this pick-and-mix approach to ideology is that it leaves considerable discretion in translating these broad approaches into policies. In the last section of this paper I will go on to demonstrate that this discretion can lead to potentially contradictory elements, at least in the field of urban policy. Although New Labour's discourse has emphasized the enduring values of social democracy - equality, citizenship, community, trans- 
parency and democracy - the link between these values and the party's urban policies is not clear and direct, and may leave the way open to the accusation that New Labour's Third Way is repackaged neo-liberalism. Before examining this link I will first need to outline New Labour's urban policy.

Table 2: The Third Way II

\begin{tabular}{|c|c|}
\hline \multicolumn{2}{|l|}{ Liberalism } \\
\hline New Labour has taken ideas on: & New Labour has rejected: \\
\hline $\begin{array}{ll}\text { - } & \text { private choice } \\
\text { - } & \text { enhancement of human capacities } \\
\text { - } & \text { furtherance of legitimate individual interests } \\
\text { - } & \text { a conpect for individual rights } \\
\end{array}$ & - $\quad$ extreme libertarianism \\
\hline \multicolumn{2}{|l|}{ Conservatism } \\
\hline New Labour has taken ideas on: & New Labour has rejected: \\
\hline $\begin{array}{l}\text { - } \\
\text { - } \quad \text { material well-being } \\
\text { the moral authority of a single order of com- } \\
\text { mon norms } \\
\text { the notion of overriding individual duties } \\
\text { towards society } \\
\text { - } \text { a romantic engagement with lost values }\end{array}$ & $\begin{array}{l}\text { - emphasis on past customs } \\
\text { - } \\
\text { action }\end{array}$ \\
\hline \multicolumn{2}{|l|}{ Socialism } \\
\hline New Labour has taken ideas on: & New Labour has rejected: \\
\hline $\begin{array}{l}\text { the idea of groups, translated into different } \\
\text { levels e.g. family and community }\end{array}$ & - $\quad$ the idea of class as a group \\
\hline
\end{tabular}

Source: Freedon (1998)

\section{NEW LABOUR'S URBAN POLICY}

In a series of publications from the Department of the Environment, Transport and the Regions (1998a and 1998b), the Department for Education and Employment (1997), the Department of Social Security (1998) and the Social Exclusion Unit (1998), the institutional structure to progress New Labour's urban policy objectives was set out. It was clear from these publications that New Labour saw area-based urban policies as no more than add-ons to mainline policies for housing, health, income support and education. Like Major before, Blair's government stressed the interactive nature of urban policy: centrally funded local programmes were set within the wider context of New Labour's national programme of social policy reforms in such areas as health, education and the New Deal Welfare for Work.

There was also continuation from Major to Blair with regard to the SRB. Soon after taking office in 1997, the first Minister for Planning and Urban Regeneration issued new guidance for Round 4 of SRB. However, when assessing bids New Labour was to attach 
more importance to community involvement, a better targeting of resources on need, and a more holistic approach to economic and social regeneration (Department of the Environment, Transport and Regions, 1997).

Beyond the stress placed by New Labour on the interactive nature of urban policy and its maintaining a SRB Challenge Fund component, Blair's government has sought to establish a critical position vis-à-vis the urban policies not only of Major's government but all governments since 1967 when Harold Wilson first introduced policy for the inner cities. Within a few months of coming to power in 1997 New Labour launched the Social Exclusion Unit (SEU) to first analyse the problems in the 1,300 most deprived neighbourhoods. The SEU's first report, launched by the Prime Minister and the Deputy Prime Minister on an estate in Hackney, London, attacked the way central and local government had failed these neighbourhoods in the past (SEU, 1998). The report stated that too much emphasis had been placed on physical regeneration and not enough on the communities themselves. It also claimed that previous efforts and funds had been wasted because of a lack of co-ordination centrally and locally.

New Labour set about providing additional support for deprived areas in the form of two new area-based programmes:

- $\quad$ Action Zones (Health, Education and Employment); and

- the New Deal for Communities (NDC).

The idea behind Action Zones was to conduct funded pilot projects to identify good practice, drawing lessons that could be applied elsewhere. The government would invite local bids for zone status and additional resources and investment thereby attracted. Employment Zones were created to trial new approaches locally to tackling unemployment in areas with high concentrations of the long-term jobless. Education Action Zones, generally focusing on two or three secondary schools and clusters of feeder primary schools with low levels of achievement in socially disadvantaged areas, were to be testbeds for innovation in the context of New Labour's determination to raise school standards. While Health Action Zones formed part of the government's drive to tackle inequalities by singling out areas with particularly high rates of ill health.

The NDC programme was introduced by the SEU in its first report (SEU,1998). On $15^{\text {th }}$ September 1998 the Department of the Environment, Transport and the Regions launched the NDC nationally. Seventeen urban areas were invited to bid for the programme, with the actual neighbourhoods being chosen at the local level. In February of the following year the Chancellor, Gordon Brown, and the Deputy Prime Minister, John Prescott, announced that ten of the seventeen proposals could go ahead with seven receiving more time to work up bids to an acceptable quality (a total of 39 projects finally received approval under the scheme). Billed as New Labour's big idea for reviving some of the country's most deprived areas, the $£ 2$ billion programme targets money at small neighbourhoods with the aim of improving job prospects, bringing together investment in people and buildings, and improving neighbourhood management and services (DETR, 1998c). The NDC's distinctive features are that it focuses on very small areas of between 1,000 and 4,000 households and 
that the range of projects that can be funded is flexible. Community-based partnerships are awarded up to $£ 50$ million to spend over ten years. While partnership working has been an evolving theme in urban policy over the last decade, the NDC aims at giving greater scope for local control over decision making and resource allocation than has been seen before.

The government intends to use the lessons learnt in the NDC programme in its more ambitious 20-year Neighbourhood Renewal (NR) programme; the origins of which are also to be found in the SEU's first report. This recommended that a National Strategy for Neighbourhood Renewal be developed, and set up 18 Policy Action Teams (PATs) to take this forward. The PATs each addressed a specific aspect of deprived neighbourhoods, ranging from housing management to financial services. Their purpose was to develop a comprehensive response and to avoid the ingrained lack of communication between traditionally delivery-oriented government departments. Indeed, New Labour's persistent use of the phrase 'joined-up government' is most prevalent in this field. In April 2000, the SEU published its National Strategy for Neighbourhood Renewal - a framework for consultation. This drew on the work of the PATs, and was put out to consultation until the end of June 2000. Finally, on 15th January 2001, a National Strategy Action Plan for NR was launched by the Prime Minister (SEU, 2001).

The Action Plan sets out the Blair government's vision for narrowing the gap between deprived neighbourhoods and the rest of the country, so that within 10 to 20 years no one should be seriously disadvantaged by where they live:

'My vision is of a nation where no-one is seriously disadvantaged by where they live, where power, wealth and opportunity are in the hands of the many not the few. This Action Plan is a crucial step in creating one nation, not separated by class, race, or where people live.' (Tony Blair, 'Foreword', SEU, 2001.)

This involves a series of targets across Whitehall to improve the figures on employment, crime, health, education and the physical environment in the poorest neighbourhoods. It aims to ensure that spending across the public sector is used to tackle these problems. At national level, the Action Plan is implemented by the Neighbourhood Renewal Unit (NRU) which is part of the Office of the Deputy Prime Minister. The Unit is responsible for driving progress across government. At regional level, neighbourhood renewal teams have been set up in the nine government offices to provide a direct channel of communication from neighbourhood/community groups to the NRU. At the local level a number of specific initiatives are associated with the Plan. Local Strategic Partnerships (LSPs) are to be set up at district level, with the role of bringing together the public, private, voluntary and community sectors so that different initiatives and services are co-ordinated rather than contradictory. LSPs will be expected to give a stronger voice to people within the various communities involved. Neighbourhood Managers are to be appointed at a level below LSPs, who will act as visible figureheads, charged with taking responsibility at the sharp end. The Action Plan also makes provision for the 88 most deprived local authority districts in the form of:

- an $£ 800$ million Neighbourhood Renewal Fund (local authorities will be free to choose how they spend it , as long as they put LSPs in place and meet the targets set out in their public service agreements); 
- a $£ 35$ million Community Empowerment Fund to help them participate in LSPs; and

- $\quad$ a $£ 50$ million Community Chest to fund local small grant schemes.

There is no doubt that New Labour's overall approach remains to tackle deprivation by targeting resources on excluded areas, with the aim of eliminating any disadvantage which people suffer because of where they live. Oatlely (2000) provides a critique of this approach by arguing that social exclusion is the result of systemic inequities that can only be addressed through broader reform. It is too early to conduct a critical appraisal of the effectiveness of New Labour's urban policy, rather by way of conclusion I want to examine its ideological leanings and point to certain tensions lying therein.

\section{CONCLUSION: THIRD WAY URBAN POLICY}

Early analysis of New Labour's actions and pronouncements reveals (in true Third Way style) a mixture of left and right. Having read some the SEU's criticisms of previous governments' urban policies - too many initiatives with too many rules; a lack of joined-up thinking; too little investment in people; too great an emphasis on physical infrastructure - we might have anticipated a fundamental reworking of urban policy. Beyond rhetoric however, there has not been a real change in approach.

New Labour's SEU puts a clear emphasis on supporting communities from below. This is not in itself a new departure since community participation was there in theory in Major's SRB, even if it was not achieved. If the focus on communities is not new, is it likely to be more effective under New Labour? To start with the communities need to be identified along with what they think. This is a difficult task made more so by the fact that the communities in question are in the process of collapse, which perhaps helps to explain why New Labour has left this issue to one side. Having been selected, are the communities really in the position to lead their projects? Early evidence from the NDC programme suggests that this may not be the case and that there are real limits on the extent to which communities can pull themselves up. Distributing grants before communities have built up the necessary capacity has led to bitter disputes and delays (Weaver, 2002a). This helps to point to one of the areas of tension in New Labour's urban policy, namely that between the delivery of short-term outputs and the longer term objective of capacity building in the communities. NDC projects with a greater degree of success in setting and delivering goals may well be those that rely on established community groups with a skills-base built-up over a number of years. How representative of the range of interests in each of their communities such groups are, and the extent to which they are favoured by government in the allocation of grants are two issues worthy of further examination.

There are also questions over the extent to which the individual NDC projects are community-led. While the communities have been given responsibility for their projects, and encouraged to develop their own agendas and approaches, they have not been given real power as the control of the resources still rests with government officials. If the proposals worked up by the communities do not meet with official approval, grants will not be 
awarded. In addition, the use of external consultants rather than local people to run the projects has led to resentment (Weaver, 2002b).

New Labour's insistence that regeneration must have the active support of communities also has to be set against the background of its macro-economic agenda, which remains firmly neo-liberal. This can be seen in the government's support of flexible and deregulated labour markets, and its 'workfare' programme. Under the government's various 'New Deal' programmes for the unemployed, the unemployed are encouraged to take 'personal responsibility' for their situation ${ }^{2}$. This paternalistic approach towards the long-term unemployed, in which the state is presented as knowing best, contrasts with its rhetoric on communityled approaches to regeneration. Yes, New Labour is concerned to address the interlinked problems of education, housing, employment, crime, etc., and to give the community a key role; but tensions are bound to arise when its macro-economic policy remains solidly neoliberal. On the one hand, communities are being encouraged to develop their own approaches; while on the other hand, there is the government direction of people whom - by a series of stick and carrot measures - are being made to take their responsibilites. We may well be left wondering, for all New Labour's emphasis on 'joined-up government', would a few policies not perhaps be better?

\section{References}

Atkinson, R. and Moon, G. 1994: Urban Policy in Britain. The City, the State and the Market, Basingstoke and London: Macmillan.

Blair, T. 1996: New Britain: My Vision of a Young Country. London: Fourth Estate.

Blair, T. 1998: The Third Way: new politics for the new century. London: the Fabian Society.

Department of the Environment, Transport and the Regions, 1998a: Regeneration Programmes - the way forward, London: DETR.

Department of the Environment, Transport and the Regions, 1998b: Community-based Regeneration Initiatives: A Working Paper. London: DETR.

Department of the Environment, Transport and the Regions, 1998c: New Deal for Communities: Phase I Proposals. London: DETR.

Department for Education and Employment, 1997: Welfare to Work Employment Zones: Local Solutions to Individual Needs. London: DFEE.

Department of Social Security, 1998: New Ambitions for Our Country: A New Contract for Welfare. London: DSS.

Edwards, J., 1997: 'Urban policy: the victory of form over substance?' Urban Studies, 34, 4-5, pp. 825-843.

Giddens, A., 1994: Beyond Left and Right: The Future of Radical Politics. Stanford, CA: Stanford University Press.

\footnotetext{
${ }^{2}$ Under the New Deal programme, introduced in January 1998, those aged 18-25 who have been unemployed for more than six months are given a period of counselling by an adviser in the Employment Service followed by the option of participating in one of a range of work or educational programmes, refusal being sanctioned with a cut in welfare benefit. Variants of the programme have been extended to other groups including single parents, those on disability benefit, and the older long-term unemployed.
} 
Giddens, A., 1998a: The Third Way: the renewal of social democracy, Cambridge: Polity Press. Giddens, A., 1998b: 'After the Left's paralysis.' New Statesman, $1^{\text {st }}$ May, pp.18-21.

Giddens, A, 2000: The Third Way and its Critics. Cambridge: Polity Press.

Hambleton, R. and Thomas, H. (eds), 1995: Urban Policy Evaluation, London: Paul Chapman Publishing.

Harris, M., 1998: 'New Labour: government and opposition.' Political Quarterly, 70, 1, pp. 42-51.

Lawless, P., 1989: Britain's Inner Cities, London: Paul Chapman Publishing.

Oatley, N., 1995: 'Competitive urban policy and the regeneration game.' Town Planning Review, 66, 1, pp.1-14.

Oatley, N., 2000: 'New Labour's approach to age-old problems - Renewing and Revitalising Poor Neighbourhoods - The National Strategy for Neighbourhood Renewal.' Local Economy, 5, 2, pp.86-97.

Parkinson, M. and Evans, R., 1989 . 'Urban development corporations.' Centre for Urban Studies Working Paper 3, Liverpool: Liverpool University Press.

Social Exclusion Unit, 1998: Bringing Britain Together: a national strategy for neighbourhood renewal, (Cm 4045), London: The Stationery Office.

Social Exclusion Unit, 2000: National Strategy for Neighbourhood Renewal - a framework for consultation. London: The Stationery Office.

Social Exclusion Unit, 2001: A New Commitment to Neighbourhood Renewal - national strategy action plan. London: The Stationery Office.

Weaver, M., 2002a: 'What's the big deal in the end?' The Observer July 7.

Weaver, M., 2002b: 'Friction slows New Deal.' The Guardian February 20.

Wilks-Heeg, S., 1996: 'Urban experiments limited revisited: urban policy comes full circle.' Urban Studies, 33, 8, pp. 1263-1297. 